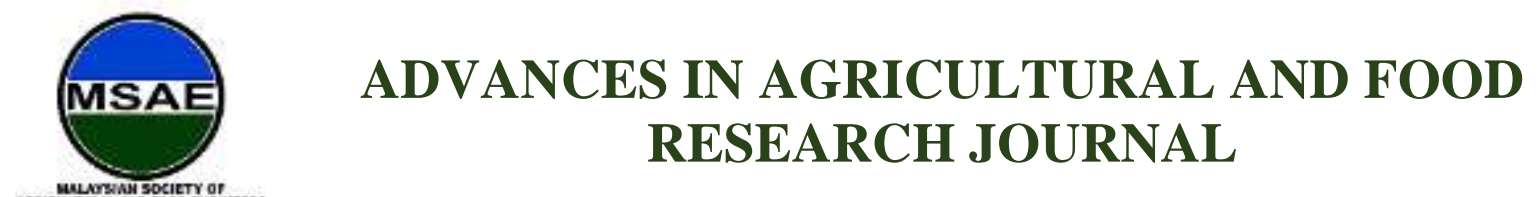

HH PUBLISHER

Original Research Article

\title{
Calibration and Performance Evaluation of Grain Corn Fertilising Implement
}

\begin{abstract}
Rohazrin Abdul Rani ${ }^{1 *}$, Adli Fikri Ahmad Sayuti ${ }^{1}$, Mohd Khusairy Khadzir ${ }^{2}$, Muhammad Haniff Ahmad ${ }^{2}$
${ }^{1}$ Engineering Research Centre, MARDI Headquartes, 43400 Serdang Selangor, rohazrin@mardi.gov.my, adlifikri@mardi.gov.my 2Engineering Research Centre, Seberang Perai MARDI Station, Pulau Pinang, mkhusairy@mardi.gov.my,
mhaniff@mardi.gov.my

*Corresponding author: Rohazrin Abdul Rani, Engineering Research Centre, MARDI Headquartes, 43400 Serdang Selangor, rohazrin@mardi.gov.my
\end{abstract}

Abstract: Fertilisation in grain corn production is an important stage that must be done properly in terms of the amount of fertiliser used to reduce wastage and ensure crop growth. A fertilising implement brand Gasprado, was calibrated and evaluated for its performance to apply urea to grain corn crops at MARDI Seberang Perai, Pulau Pinang. Calibration was conducted to set the right metering for the device's opening to drop urea that meets the application rate of $130 \mathrm{~kg} / \mathrm{ha}$. This was done by measuring the amount of urea dropped for a particular setting and distance. The machine has four metering devices which were labelled as MD1, MD2, MD3 and MD4. Additionally, the fertiliser applicator also comes with spring tine cultivating devices. The implement was tested for fertilising 56 rows of grain corn in the distance of $62 \mathrm{~m}$ long. The times taken for the tractor to finish four rows per run along the 62-m distance and to turn at the headland were recorded to evaluate the performance. The implement's metering devices MD1, MD2, MD3 and MD4 were calibrated at setting scales of B-1.5, B-0, B-0 and B-0, respectively that gave the urea application rate of $133 \mathrm{~kg} / \mathrm{ha}$, which was the nearest rate to the recommendation. The average working speed of the operation was at $4.08 \mathrm{~km} / \mathrm{h}$ with the theoretical field capacity to be at $1.224 \mathrm{ha} / \mathrm{h}$. Meanwhile, the machine's effective field capacity was $0.5208 \mathrm{ha} / \mathrm{h}$, which had a field efficiency of 42.5 $\%$ for the particular farm design. The use of machine can speed up the operation of applying fertiliser to the grain corn crop but the performance is dependent on the farm layout.

Keywords: Fertilising implement, Calibration, performance evaluation, and grain corn

Received: $29^{\text {th }}$ March 2021

Received in revised form: $16^{\text {th }}$ June 2021

Citation: Rani, R. A., Sayuti, A. F. A., Khadzir, M. K., et al. Calibration and performance evaluation of grain corn

Accepted: $20^{\text {th }}$ June 2021 fertilizing implement. Adv Agri Food Res J 2021; 2(2): a0000227.

Available Online: $2^{\text {nd }}$ July 2021 https://doi.org/10.36877/aafrj.a0000227 


\section{Introduction}

In Malaysia, grain corn is one of important ingredients in formulation of animal feeds especially for poultry. Nearly $100 \%$ source of grain corn in Malaysia is dependent on imported product (Knoema, 2020). Currently, the grain corn industry in Malaysia is in a redeveloping stage since several trials conducted previously were met with failures due to the lack of economic viability for local production to meet the same expectations from imported products (Nor et al., 2019).

The redevelopment of the grain corn industry in Malaysia focuses on large-scale production systems. The main key importance in achieving the target is in field mechanisation technology. Field mechanisation technology is involved throughout the production operation of grain corn which begins from the preparation of the soil, followed by planting, maintenance of crops including fertilising, irrigation, harvesting and management of crop residues.

Fertilisation in grain corn production is an important stage that must be done properly in terms of the amount of fertiliser used in order to reduce wastage and ensure crop growth. One of the fertiliser operations in grain corn production involves top dressing. Top dressing operation is an application of urea (46\% Nitrogen) between crop ages of 25 to 28 days after planting (Bahagia \& Sheng, 2019). A typical tractor with 45 to $50 \mathrm{~cm}$ ground clearance may only be used in corn farm when the maximum crop age reaches 28 days after planting. In this age, the average crop height is about $46 \mathrm{~cm}$ tall (Wardhani et al., 2013). As agronomist practices, grain corn crop requires about $120 \mathrm{~kg}$ nitrogen $(\mathrm{N}), 60 \mathrm{~kg}$ phosphorus $(\mathrm{P})$, and 40 $\mathrm{kg}$ potassium $(\mathrm{K})$ along the life period of 120 days (Bahagia \& Sheng, 2019). The nitrogen is provided to the crops in two different applications, first during planting and second, as described above. The first fertiliser application is at $400 \mathrm{~kg} / \mathrm{ha} \mathrm{N}-\mathrm{P}-\mathrm{K}$ green $(15: 15: 15)$ which is equivalent to $60 \mathrm{~kg} / \mathrm{ha} \mathrm{N}$ using fertilising applicator that is integrated with planting implement. The second application is at $130 \mathrm{~kg} / \mathrm{ha}$ urea $(46 \% \mathrm{~N})$ which is applied using dedicated fertiliser applicator cum with inter row cultivating system (Bahagia \& Sheng, 2019; Rohazrin et al., 2019).

A uniform distribution of fertiliser is assured by correct calibration and maintenance of implement or equipment (Zekri et al., 2011). Calibration decreases production costs and fertiliser transport to local surface waters, along with other management activities. Fertilising implement that have not been adequately maintained and calibrated would have trouble applying the grown crop with specific rates and uniformity in dispersing accurate quantities of fertiliser. Compared to cost that can be incurred by incorrect application rates; the amount of time needed to correctly manage and calibrate an implement is negligible.

The objective of this paper is to explain the method of calibration and the performance evaluation of the grain corn fertilising implement in applying urea for top dressing application. This article can be a guide for Malaysian farmers especially of those who are involved in grain corn industry in order to optimize the application of fertiliser. 


\section{Materials and Methods}

\subsection{Machine Specifications}

The application of urea for top dressing operation was done using fertilising implement brand Gasprado with an overall dimension of $1.5 \times 2.5 \times 1.5 \mathrm{~m}(\mathrm{~L} \times \mathrm{W} \times \mathrm{H}$. $)$ The machine has two main components composed of an inter row cultivating mechanism and fertilising applicator as shown in Figure 1(a). The inter row cultivating mechanism comprises of five sets of spring tine cultivators spaced $75 \mathrm{~cm}$ apart that can fit four rows of crop as shown in Figure 1(b). Two of the spring tine sets are half dimension of the other three, with $30 \mathrm{~cm}$ width placed at the first and end set. This cultivating mechanism was used as weeds control tools and to cultivate soil to mix with fertiliser.

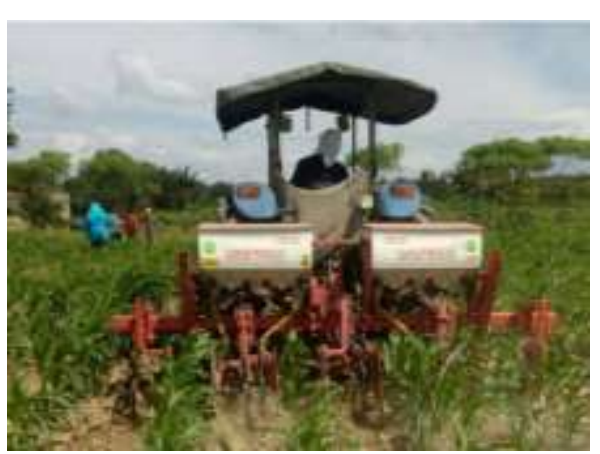

(a)

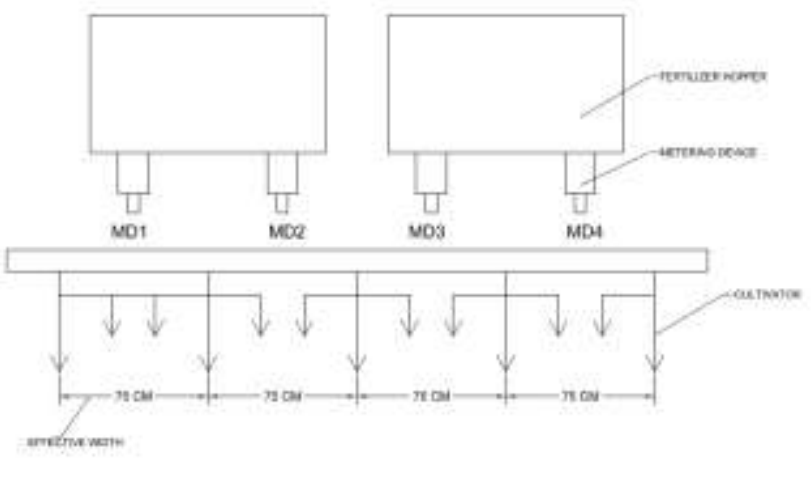

(b)

Figure 1. (a) Fertilising implement; (b) Illustration of the mechanism.

\subsection{Fertiliser Applicator Specifications}

The fertiliser applicator was divided into two sections: the fertiliser hopper and the metering devices. The fertiliser hopper can store up to $400 \mathrm{~kg}$ of fertiliser per operation, which was divided into two hoppers, each with $200 \mathrm{~kg}$ of fertiliser. Each hopper as further equipped with two metering devices which guided by one ground wheel driven gearing system as shown in Figure 1(a). The metering device (Figure 2) controls the amount of fertiliser drop to crop by setting the opening outlet gate. The setting can be adjusted using screw type sliding gate that has indicator $\mathrm{A}$ to $\mathrm{F}$ at the screw guide and number 0 to 9 at the ring-nut. These two indicators gave 60 combinations of the opening gate scale from the smallest A-0 to largest F-9. Only granular type fertiliser can be used for the type of metering system. Fertiliser was distributed to the ground through a corrugated hose that connects the metering device to the coulter opener. The fertiliser then mixed with soil through the action of spring tine cultivator. 


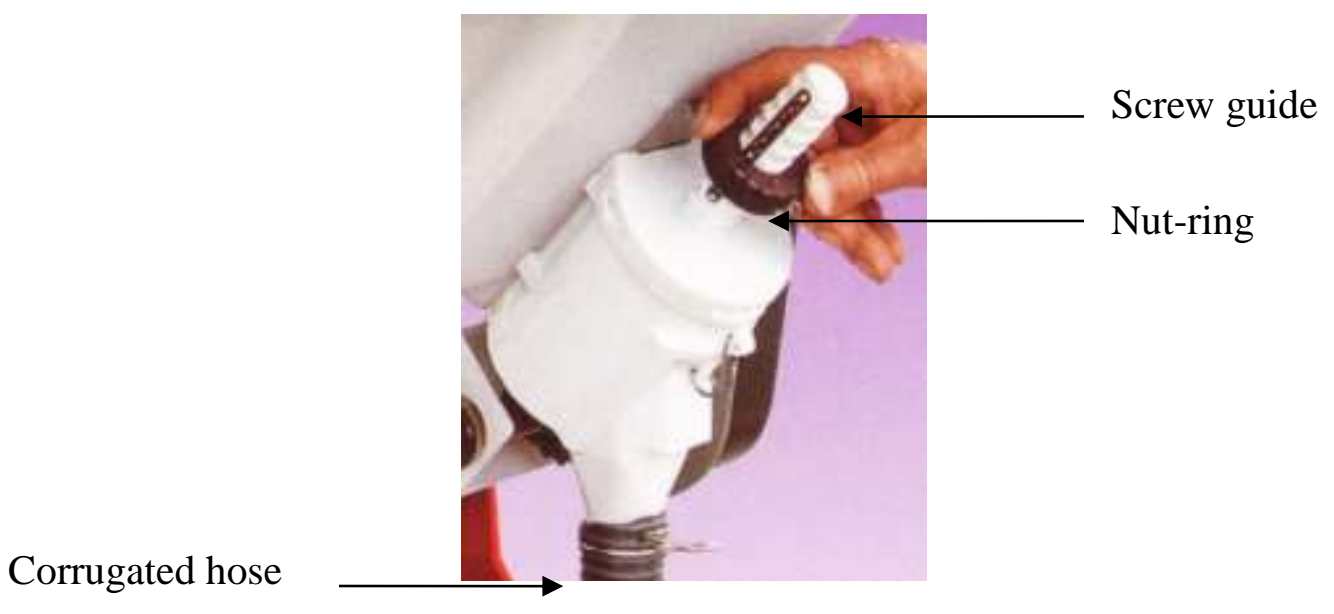

Figure 2. Fertiliser metering device

\subsection{Calibration of the metering device}

Calibration was conducted to set the right metering device's gate opening scale to meet the recommended urea application rate of $130 \mathrm{~kg} / \mathrm{ha}$. This was done by measuring the amount of urea dropped in a particular traveling distance and the scale setting of the metering device. The four metering devices were labelled MD1, MD2, MD3 and MD4 from left to right as in Figure 1(b). In order to get $130 \mathrm{~kg} / \mathrm{ha}$ fertiliser, each metering device shall give about $0.195 \mathrm{~kg}$ in $20 \mathrm{~m}$ running distance. This was calculated as below:

Running distance of an each metering device per ha $=$

$$
\frac{10000 m^{2}}{0.75 m}=13,333.33 m
$$

Where,

$0.75 \mathrm{~m}$ is the effective working width for each metering device $=$ crop row spacing

Weight of fertiliser at $20 \mathrm{~m}$ running distance $=$

$$
\frac{130 \mathrm{~kg} \times 20 \mathrm{~m}}{13,333.33 \mathrm{~m}}=0.195 \mathrm{~kg}
$$

Where,

$130 \mathrm{~kg}$ is the recommended urea application rate per ha

The fertiliser was collected in plastic bags tied to the outlet hose tips during calibration, and the weight was determined using a digital scale. Plastic bags were placed slightly higher than the ground to avoid being ripped off by rough ground surfaces. The calibration setting was first done by trial and error method. The first result determined the next scale setting whether to increase or subtract the fertiliser amount. The calibrations were 
done until the setting meet the required amount of fertiliser as recommended. The final setting which had the correct amount of fertiliser was tested for a longer travel distance of $40 \mathrm{~m}$ long to verified the setting stability.

\subsection{Field Evaluation}

The implement was evaluated for fertilising 56 rows or 14 passes of grain corn in the distance of $62 \mathrm{~m}$ long at MARDI Seberang Perai, Pulau Pinang experimental plot. Time taken for the tractor to complete four rows per running operation along $62 \mathrm{~m}$ distance and to turn at the headland were recorded to evaluate the theoretical field capacity. The actual time taken to finish the 56 rows including the time losses during operation such as, mishandling, turning at the end rows and breakdown repairs was recorded to obtain the effective field capacity of the operation. The theoretical and effective field capacities were compared to obtain the field efficiency of the running operation in the particular farm layout. The equations used for obtaining the above information are as follows:

Theoretical field capacity

$$
T F C=\frac{W \times S}{C}
$$

Where, TFC = theoretical field capacity, $\mathrm{W}=$ the width between-row spacing $(\mathrm{m}), S$ $=$ the average forward speed $(\mathrm{km} / \mathrm{h})$ and $C=$ constant, 10

Effective capacity

$$
E F C=W \times S \times F E=T F C \times F E
$$

Where, $\mathrm{EFC}=$ effective field capacity which is the work rate achieved over the whole plot with considering the total time taken for the work done at the plot,

Also EFC can be obtained as,

$$
E F C=\frac{\text { Total area }(h a)}{\text { total time taken }(h)}
$$

Field efficiency, in \%

$$
\mathrm{FE}=\frac{\mathrm{EFC}}{\mathrm{TFC}} \times 100
$$


The particular setting (the calibrated setting) used for fertilising 1.3 ha grain corn plot and total amount of urea used were recorded. In order to minimise the error for calculating the efficiency of urea application for the calibrated setting compared to recommended rate, actual farm size was obtained by measuring each tractor travelled path distance.

The urea application efficiency $(\%)$ was obtained by,

$$
U A=\frac{\text { calibrated fertilizer rate }}{\text { recommendation fertilizer rate }} \times 100
$$

\section{Results and Discussions}

\subsection{Calibration}

The following Table 1 shows the result taken during the calibration. The first trial and error calibration setting was scale $\mathrm{C}-0$ that gave the average weight of the fertiliser collected in $20 \mathrm{~m}$ distance which was more than recommended weight of $0.195 \mathrm{~kg}$ for all metering devices valued between 0.28 to $0.32 \mathrm{~kg}$. From the first results, it was expected that each scale between A-0 up to C-0 gave an increment of fertiliser weight of $0.1 \mathrm{~kg}$, and so the following calibration tested was scale B- 0 and gave the calibrated weight of the fertiliser near to the recommended rate which were $0.2 \mathrm{~kg}$ except for metering device MD1 that measured below the recommended rate with a value of $0.18 \mathrm{~kg}$. Then, metering device MD1 was calibrated alone by increasing the scale to B-2, but the additional scale of 2 gave the fertiliser weight exceeded the requirement to a value of $0.22 \mathrm{~kg}$. Consequently, the scale on the metering device was reduced to B-1.5 which is in the middle between scales 1 and 2 and this gave fertiliser weight of $0.2 \mathrm{~kg}$ which near to recommended rate.

Table 1. Metering device calibration on $20 \mathrm{~m}$ running distance.

\begin{tabular}{lccccc}
\hline Calibration setting & \multicolumn{3}{c}{ Average weight of fertiliser collected (kg) } & \multicolumn{2}{c}{ Acceptance } \\
\hline Metering Device No. & MD1 & MD2 & MD3 & MD4 & no \\
C-0 & 0.3 & 0.32 & 0.31 & 0.28 & 0.2 \\
B-0 & 0.18 & 0.2 & 0.2 & Yes except MD1 \\
B-2 & 0.22 & nil & nil & nil & no \\
B-1.5 & 0.2 & nil & nil & nil & Yes \\
\hline
\end{tabular}

From the result obtained, the fertiliser applicator's metering devices MD1, MD2, MD3 and MD4 were calibrated to setting configuration scale of B-1.5, B-0, B-0 and B-0, respectively.

Re-testing for all metering devices was done simultaneously for a distance of $20 \mathrm{~m}$ and a greater distance of $40 \mathrm{~m}$ to verify the calibrated scale configuration of the metering devices. The results of the verification of the calibrated scale are as in Table 2. 
Table 2. Verification of the calibrated scale.

\begin{tabular}{lllllll}
\hline Metering Device No. & $\mathbf{1}$ & $\mathbf{2}$ & $\mathbf{3}$ & $\mathbf{4}$ & Total & Acceptance \\
\hline Configuration & B-1.5 & B-0 & B-0 & B- 0 & & \\
Test $1(20 \mathrm{~m})$ & 0.20 & 0.20 & 0.20 & 0.20 & 0.8 & yes \\
Test $2(40 \mathrm{~m})$ & 0.40 & 0.42 & 0.40 & 0.42 & 1.64 & yes \\
Test $3(40 \mathrm{~m})$ & 0.39 & 0.41 & 0.40 & 0.39 & 1.59 & yes \\
\hline
\end{tabular}

The total fertilisers at distances of 20 and $40 \mathrm{~m}$ were calculated to be $0.78 \mathrm{~kg}$ and 1.56 $\mathrm{kg}$, respectively, but during calibration verification, the average collected fertiliser was 0.8 $\mathrm{kg}$ and $1.62 \mathrm{~kg}$, respectively, resulting in a urea rate application of $133 \mathrm{~kg} / \mathrm{ha}$, which was slightly higher than the recommended rate of $130 \mathrm{~kg} / \mathrm{ha}$. Despite the additional fertiliser, this setting was deemed acceptable because there would be some error during operation due to wheel slippage and uneven surface, which would affect the fertiliser volume. For crop development and yield produce, more fertiliser is preferable to less in order to avoid deficient effects on the crop,but not at an excessive rate, which would go to waste and pollute the environment (Gagnon et al., 2012).

\subsection{Field Performance}

The average time taken for the tractor to travel and turn at headland during the fertilisation operation is shown in Table 3. The tractor took an average of $54.67 \pm 7.4 \mathrm{~s}$ to travel and $40.36 \pm 7.5 \mathrm{~s}$ to turn. These results were the averages of 14 measurements taken over a 62-m distance. The 56-row grain corn fertilising process took around 30 minutes to complete, starting at 15:23 p.m. and ending at 15:53 p.m.

Table 3. Average time taken for tractor travelling, turning and overall operation

\begin{tabular}{ccc}
\hline Travelling time for $62 \mathrm{~m}(\mathrm{~s})$ & Turning time (s) & $\begin{array}{l}\text { Overall time for the operation } \\
\text { including down time (minute) }\end{array}$ \\
\hline $54.67 \pm 7.4$ & $40.36 \pm 7.5$ & 30 \\
\hline
\end{tabular}

Table 4 shows the fertilisation operation's performance evaluation. The operation's average operating speed was $4.08 \mathrm{~km} / \mathrm{h}$, with a potential field capacity of $1.224 \mathrm{ha} / \mathrm{h}$. Meanwhile, the machine's effective field capacity was $0.5208 \mathrm{ha} / \mathrm{h}$, resulting in a $42 \%$ field efficiency for the specific farm design. One of the factors that affect machine performance was improper farm design. A tractor was spotted struggling to turn at a narrow headland. The tractor turned in an average of 40.36 seconds, indicating that there were insufficient farm headland areas for the tractor to turn. A tractor (New Holland, $85 \mathrm{hp}$ ) with an overall width of $2 \mathrm{~m}$ and turning radius of $4 \mathrm{~m}$ must have a minimum headland space of $5 \mathrm{~m}$ to turn (Spekken \& de Bruin, 2013). 
Table 4. Theoretical field capacities, effective field capacity and field efficiency of the top dressing operation (urea application)

\begin{tabular}{cccc}
\hline $\begin{array}{c}\text { Average Forward speed } \\
(\mathrm{km} / \mathrm{h})\end{array}$ & $\begin{array}{c}\text { Theoretical field capacity } \\
(\mathrm{ha} / \mathrm{h})\end{array}$ & $\begin{array}{c}\text { Effective field capacity } \\
(\mathrm{ha} / \mathrm{h})\end{array}$ & Field efficiency $(\%)$ \\
\hline 4.08 & 1.224 & 0.5208 & 42.5 \\
\hline
\end{tabular}

The actual size of the testing plot was slightly smaller than anticipated. The area was calculated only on the basis of the planted area, with a total acreage of 1.26 ha, giving a planting area efficiency of $97 \%$ from the stated area of 1.3 ha. Using the calibrated scale setting, the amount of urea $(\mathrm{N}, 46 \%)$ used for a 1.26 ha area was $159 \mathrm{~kg}$, with a urea rate application of $126 \mathrm{~kg} / \mathrm{ha}$, which was $4 \mathrm{~kg} / \mathrm{ha}$ less than the recommended rate of $130 \mathrm{~kg} / \mathrm{ha}$. This could be caused by wheel slippage or other causes that were difficult to determine. The summary of the fertilising operation is as shown in Table 5 . The figure of $3.8 \mathrm{~kg}$, which is the difference in fertilizer applies compare to recommended rate indicates that the urea application was $96.9 \%$ efficient. For machine application, the application efficiency can be deemed nearly perfect.

Table 5. Fertilising operation of 1.3 ha grain plot

\begin{tabular}{cccccc}
\hline Actual plot size & $\begin{array}{l}\text { Amount of } \\
\text { fertilizer used }\end{array}$ & Fertilising rate & $\begin{array}{l}\text { Different of } \\
\text { recommend rate } \\
(130 \mathrm{~kg} / \mathrm{ha}) \\
(\mathrm{kg} / \mathrm{ha})\end{array}$ & $\begin{array}{c}\text { Area efficiency } \\
(\%)\end{array}$ & $\begin{array}{l}\text { urea rate } \\
\text { application } \\
\text { efficiency } \\
(\%)\end{array}$ \\
\hline 1.26 & $(\mathrm{~kg})$ & $(\mathrm{kg} / \mathrm{ha})$ & 3.8 & 97 & 96.9 \\
\hline
\end{tabular}

\section{Conclusions}

The application of urea for cornfield top dressing at MARDI Seberang Perai, Pulau Pinang, showed $96.9 \%$ efficiency on the amount of urea applied to the field. This indicates that a good calibration has been done, however, the $42.5 \%$ efficiency on the field operation indicates that the farm layout design needs to be improved. Calibration is necessary to ensure that agricultural inputs, particularly fertiliser, are distributed uniformly. The use of machines can speed up the fertiliser application process; however the results are dependent on the farm layout. The design of the farm layout should be based on the machinery to be utilized in order to maximize the efficiency of the operation on the farm. A high efficiency of machinery operation could assist farmers in optimizing their use of agricultural inputs while maintaining a low cost.

Funding: This research was supported and funded by Ministry of Agriculture and Agro Food, Malaysia under New Wealth Resources project program. 
Conflicts of Interest: The authors declare no conflict of interest.

\section{References}

Bahagia, A. G. M., \& Sheng, C. C. (2019). Potensi penanaman jagung bijian di Malaysia: Pengalaman MARDI. Laporan Khas MARDI.

Gagnon, B., Ziadi, N., \& Grant, C. (2012). Urea fertilizer forms affect grain corn yield and nitrogen use efficiency. Canadian Journal of Soil Science, 92(2), 341-351.

Knoema. (2020). Malaysia maize import quantity. Retrieved from https://knoema.com/atlas/Malaysia/topics/Agriculture/Trade-Import-Quantity/Maize-imports-quantity.

Nor, N. A. A. M., Rosali, M. H., Rabu, M. R., et al. (2019). An overview of the grain corn industry in Malaysia. FTTC Agricultural Policy Platform. https://ap.fftc.org.tw/article/1377

Rohazrin, A. R., Fikri, A. S. A., \& Khusairy, K. M. (2019). Mekanisasi pengeluaran jagung bijian. In Laporan Khas Potensi Penanaman Jagung Di Malaysia: Pengalaman MARDI. ISBN 978-967-936-672-3.

Spekken, M., \& de Bruin, S. (2013). Optimizing routes on agricultural fields minimizing maneuvering and servicing time. Precision Agriculture. 14. 10.1007/s11119-012-9290-5.

Wardhani, W., \& Kusumastuti, P. (2013). Describing the height growth of corn using Logistic and Gompertz model. AGRIVITA Journal of Agricultural Science, 35, 237-241. 10.17503/Agrivita-2013-35-3-p237241.

Zekri, M., Futch, S., \& Atwood, R. (2011). Importance of fertilizer spreader and sprayer calibration and maintenance. Retrieved from https://crec.ifas.ufl.edu/extension/trade_journals/2011/2011_May_fertilizer_spreader.pdf. 